\title{
Determination of Heavy Metals in Waste Dumpsites in Lafia Town and Environs
}

\author{
Solomon J. Anzene \\ Department of Science Laboratory Technology, \\ Nasarawa State Polytechnic, Lafia, \\ Nigeria
}

\begin{abstract}
The potential threat of heavy metals from urban waste dumpsites to human health has led to many studies to investigate their levels of concentrations of these elements. In this study, ten (10) samples were obtained from the five different zones within Lafia town and environs. The levels/concentrations of these metals were determined using Atomic Absorption Spectrophotometer (AAS) and is aimed at assessing the levels and risk of heavy metals, contamination in waste dumpsites in Lafia and its environs. The analysis revealed that the mean concentrations of $P b(138.456 \mathrm{mg} / \mathrm{kg})$, Cd $(7.2813 \mathrm{mg} / \mathrm{kg}), \mathrm{Zn}(432.296 \mathrm{mg} / \mathrm{Kg}), \operatorname{Se}(0.515 \mathrm{mg} / \mathrm{kg})$, at the waste dumpsites observed exceeded their WHO/FAO guidelines and geochemical backgrounds reported in the literature. While $\mathrm{Pb}$ and $\mathrm{Zn}$ were observed in all the sites, $\mathrm{Cd}$ and Se were detected in only 3 to 4 out of the 10 sites analysed. However, the concentrations of $\mathrm{As}, \mathrm{Cr}, \mathrm{Fe}, \mathrm{Cu}, \mathrm{Mn} \mathrm{Ni} \mathrm{Ba}$, Co were within tolerable limits and therefore pose no risk. These metals originate from both natural and anthropogenic sources, gradual build-up of toxic metals in the dumpsites. The study recommends putting adequate measures and creating awareness so as to monitor and mitigate any ill effects arising from uncontrolled disposal of wastes to prevent harm to the environment and jeopardizing our health and upsetting the balance of nature.
\end{abstract}

Keywords: Heavy metals, contamination, concentration, anthropogenic, environment

\subsection{INTRODUCTION}

All wastes have the potential to cause environment damage. One of the recent global challenges facing towns and cities is solid waste management. The pressure of population growth produces stresses that cause environmental degradation and in particular solid waste thereby polluting air, water and land on which all life so critically depends (Akaeze,2001). Going by the resource and energy demand on the environment and the internal pollution that man inflicts upon himself by inhalation and ingestion of alien chemical substances, man is best described as a chemical factory in terms of materials use and waste.

The most common pollutants found in refuse dumps are heavy metals. These metals enter into our environment from both natural and anthropogenic sources. They contaminate food source and accumulate in both agricultural products and soils and other environmental components through water, air and soil pollution (KabataPendias, 2011).

Soils are the major sinks of heavy metals released into the environment through waste disposals; municipal, medical/pharmaceutical wastes etc; and unlike other organic contaminants which are oxidized to carbon (IV) oxide by microbial action. Most metals do not undergo microbial or chemical degradation, and their total concentrations in soils persists for a long time after their introduction (Zauro et al, 2013).

Heavy metals, sometimes called "trace elements" are typically classified into two major forms including essential and non-essential metals. Essential heavy metals have beneficial role in living things at certain concentration. Some of these important heavy metals include Iron, Manganese, Copper, Zinc, Chromium among others. High concentration of essential metals in biological system could lead to toxicity on the exposed organisms. While others such as Lead, Cadmium, Mercury and Arsenic have no known role in living organisms and as such, they are highly lethal even at low concentration (Sylvester et al, 2017).

Heavy metals are elements with high relative atomic mass. The term is common to transition metals such as $\mathrm{Cu}, \mathrm{Pb}$, $\mathrm{Hg}, \mathrm{As}, \mathrm{Zn}, \mathrm{Cr}$, Fe (Ali et al, 2005). These metals cause environmental pollution from a number of sources including dumpsites where leaching of metals ions from soil into lakes rivers by rain occur. Heavy metals are nonbiodegradable pollutants which eventually bioaccumulate in the environment and may be concentrated in food chain. Lafia, being a major city in North Central Nigeria is faced with waste disposal problems near residential areas and other public places. Therefore it is a common site to find huge dumpsites within residential areas along major and minor roads.

Poor waste management, improper collection and disposal of refuse are among the key factors responsible for the multiple of problems threatening the Nigeria's environment (Iwegbue et al ,2007). Many heavy metals, $\mathrm{Pb}, \mathrm{Hg}$, As, Cd, $\mathrm{Ba}, \mathrm{Ag}$ which are known poisons are present in wastes.

Most of the heavy metals enter the food chain via plant uptake. Vegetables absorb these metals from the ground, as well as from deposits on the parts of vegetables exposed to air from polluted environment.

Many inorganic can accumulate in plants and result in toxic effects to animals and human, such as anaemia and kidney malfunctioning. Hence due to various devastating effects of heavy metals in human, it is significant to ascertain the levels of these heavy metals contamination and advice the Government and populace of the danger and ways of mitigating them

Heavy metals are natural constituents of the earth's crust and human activities have drastically altered or changed the balance, biochemical and geochemical cycles of some heavy metals. Environmental pollution, is a result of man's 
increasing activities such as improper waste disposal due mainly to the significant increase in economic activities and industrialization (Sanayei et al ,2009). Due to the accumulation of heavy metals in biological systems through contaminated water and soil, therefore a better understanding of heavy metals sources, their accumulation and their effect of their presence in water, soil and plant system is important particularly on risk assessment.

\subsection{MATERIALS AND METHODS}

\subsection{Study area}

The study area is Lafia metropolis with about fifty neighbhoods. Lafia is the capital of Nasarawa State which is located in the Middle Belt Region of Nigeria. The state lies between longitude $7^{\circ}$ and $9^{\circ} 37^{\prime} \mathrm{E}$ of the Greenwich Meridian and has an absolute of $181.5 \mathrm{~m}$ above sea level (Akwa et al,2007).

Lafia is located within the geological Afo Younger Granites complex within the Middle Benue Trough. Afo younger granite complex is the younger granite complex in Nigeria. The Younger Granites are distinctive series of alkali feldspar granite hosting minerals like cassitterite, columbites as major minerals. Lafia which is the last segment of the Middle Benue trough is underlined by basement complex rocks and has appreciable layer of sedimentation notable for water detention (Okegye,2010).

\subsection{Sample collection and preparation}

Soil samples (wastes) of topsoil $(0-12 \mathrm{~cm})$ were collected from dumpsites in each of the five zones of Lafia metropolis (North, South, East, West and Central). Composite samples were made out of them in a polyethylene bag and taken to the laboratory for analysis.
The samples were air dried, ground to pass through a $2 \mathrm{~mm}$ sieve using mortar and pestle.

\subsection{Determination of $\mathrm{pH}$}

The $\mathrm{pH}$ of the samples were determined by adding $25 \mathrm{ml}$ of distilled water to $10 \mathrm{~g}$ of air dried and sieved soil sample. The mixture was stirred for 10 minutes and allowed to stand for 1 hour. The electrode of the $\mathrm{pH}$ meter was immersed into the slurry and readings are taken (Obaliagbon et al, 2006).

\subsection{Digestion of samples}

$2.0 \mathrm{~g}$ of the sieved soil samples was digested for 3hours at $85^{\circ} \mathrm{C}$ in $12 \mathrm{ml}$ of aqua regia $\left(3: 1 \mathrm{HCl}-\mathrm{HNO}_{3} \mathrm{v} / \mathrm{v}\right)$ using a hot plate in a fume cupboard until white fumes are observed. The sample was allowed to cool to room temperature and then dilute with $20 \mathrm{ml}$ of $2 \%$ Nitric Acid (v/v). The mixture was then transferred into a $100 \mathrm{ml}$ volumetric flask after filtering using Whatman No. 42 filterpaper and made to mark with distilled water. The extracts (digested soil waste samples) were analyzed for the heavy materials; $\mathrm{Pb}$, As, $\mathrm{Cd}, \mathrm{Cr}, \mathrm{Fe}, \mathrm{Zn}, \mathrm{Se}, \mathrm{Cu}, \mathrm{Mn}, \mathrm{Ni}, \mathrm{Be}, \mathrm{Co}$; using Atomic Absorption Spectrophotometer (AAS: iCE 3000 series).

\section{$2.5 \quad$ Statistical tools}

The results obtained was analyzed statistically by using the Mean (x) Coefficient of Variation (CV) and Standard Deviation(SD).

\subsection{RESULTS AND DISCUSSION}

Table 3.1 presents the summary of results, the $\mathrm{pH}$, mean concentrations of Heavy metals studied in waste dumpsites from the study area.

Table 3.1 Summary of the $\mathrm{pH}$ and mean concentration of heavy metals in waste dumpsites from the study area.

\begin{tabular}{|c|c|c|c|c|c|c|c|}
\hline \multicolumn{8}{|c|}{$\mathrm{mg} / \mathrm{kg}$} \\
\hline Sample/Site & $\mathrm{pH}$ & $\mathrm{Cd}$ & $\mathrm{Pb}$ & As & $\mathrm{Cr}$ & $\mathrm{Fe}$ & $\mathrm{Zn}$ \\
\hline 1 & 6.32 & 16.325 & 239.103 & 4.551 & 11.478 & 2027.155 & 203.130 \\
\hline 2 & 6.57 & ND & ND & 6,352 & 11.489 & 2166.120 & 23.895 \\
\hline 3 & 6.12 & ND & 24.185 & 2.445 & 24.243 & 2728.003 & 517.925 \\
\hline 4 & 5.94 & 1.493 & 401.918 & 1.002 & 26.228 & 2738.008 & 965.375 \\
\hline 5 & 5.92 & 4,026 & 25.490 & 0.664 & 14.700 & 2195.450 & 197.113 \\
\hline 6 & 5.89 & ND & 68.660 & ND & 14.455 & 2494.340 & 681.995 \\
\hline 7 & 5.67 & ND & 16.555 & ND & 8.823 & 2691.188 & 32.555 \\
\hline 8 & 5.87 & ND & 98.020 & 0.642 & 15.168 & $2821 . .578$ & 427.548 \\
\hline 9 & 5.90 & ND & 233.718 & 0.338 & 23.668 & 2966.230 & 1149.78 \\
\hline 10 & 5.97 & ND & ND & 4.165 & 13.558 & 2673.110 & 123.640 \\
\hline $\bar{X}$ & 6.02 & 7.2813 & 138.456 & 2.520 & 16.381 & 2550.118 & 432.296 \\
\hline SD & \pm 0.25 & +7.934 & +139.28 & +2.254 & +6.082 & +315.992 & +394.171 \\
\hline $\mathrm{CV}(\%)$ & $\overline{4} .15$ & $\overline{108.96}$ & $\overline{1} 00.60$ & $\overline{8} 9.44$ & $\overline{3} 7.13$ & $\overline{1} 2.39$ & $\overline{9} 1.18$ \\
\hline
\end{tabular}

\begin{tabular}{|c|c|c|c|c|c|c|}
\hline \multirow[b]{2}{*}{ Sample/Site } & \multicolumn{6}{|c|}{$\mathrm{mg} / \mathrm{kg}$} \\
\hline & $\mathrm{Se}$ & $\mathrm{Cu}$ & $\mathrm{Mn}$ & $\mathrm{Ni}$ & $\mathrm{Ba}$ & Co \\
\hline 1 & ND & 48.425 & 69,890 & 5.475 & 2.315 & 1.590 \\
\hline 2 & ND & 4.390 & 95.950 & 0.580 & 6.331 & 0.393 \\
\hline 3 & ND & 7.048 & 191.918 & 2.188 & 1.002 & 4.123 \\
\hline 4 & 0.623 & 24.430 & 238.595 & 1.068 & 5.612 & 2.423 \\
\hline 5 & 0.335 & 10.365 & 130.590 & 0.173 & 7.468 & 1.405 \\
\hline 6 & ND & 93.153 & 193.183 & 3.855 & 9.331 & 0.498 \\
\hline 7 & ND & 12.638 & 160.703 & ND & 10.201 & 0.495 \\
\hline 8 & ND & 16.663 & 237.703 & 0.800 & 15.612 & 1.720 \\
\hline 9 & 0.887 & 19.428 & 309.563 & 1.645 & 0.365 & 1.888 \\
\hline 10 & 0.214 & 16.623 & 123.513 & ND & 4.991 & 1.815 \\
\hline$\overline{\mathrm{X}}$ & 0.515 & 25.32 & 175.161 & 1.973 & $6 . .323$ & 1.635 \\
\hline $\mathrm{SD}$ & \pm 0.302 & \pm 26.83 & \pm 73.654 & \pm 1.826 & \pm 4.641 & \pm 1.111 \\
\hline $\mathrm{CV} \%$ & $\overline{58.64}$ & 105.96 & $\overline{4} 2.05$ & $\overline{9} 2.55$ & $\overline{7} 3.40$ & $\overline{6} 7.95$ \\
\hline
\end{tabular}


Key:

$\overline{\mathrm{X}}=$ mean

SD: Standard Deviation

CV: Co-efficient of Variation

ND:Not Deducted

The $\mathrm{pH}$ of the study area ranged from 5.67 to 6.32 with a mean value of 6.02. The slight acidic values might be due to the dumping of acid containing waste materials like batteries on the dumpsites. The overall mean $\mathrm{pH}$ indicated acidic soil and this is attributed to industrial pollution of acidic gases, effect of bush burning and the harmattan dust (Esu, 1987). pH is very critical for most metals, since metal availability is relatively low when the $\mathrm{pH}$ is around 6.5-7; with the exception of Mo, Se and As; the mobility of metals decreases with increasing $\mathrm{pH}$ because of the formation of insoluble hydroxide, carbonate and organic complexes (Iwegbue, 2010).

The concentration of Cadmium range from $1.493 \mathrm{mg} / \mathrm{kg}$ to $16.325 \mathrm{mg} / \mathrm{kg}$ with a mean value of $7.2813 \mathrm{mg} / \mathrm{kg}$ above $3 \mathrm{mg} / \mathrm{kg}$ the permissible limit or tolerable levels (Kloke, 1979; Kabata,2011). Apart from S1, S4 and S5, Cadmium was not detected in seven dumpsites. Cadmium is very much connected with non-residual fractions of heavy metals and thus makes them mobile and potentially bioavailable for uptake by plants (Benedicta,2017). The high concentration of $\mathrm{Cd}$ at $\mathrm{S} 1$ might be as a result of burning of electronic waste containing Cadmium-Nickel batteries, pigments and paints. Significant concentration of cadmium may have gastrointestinal effect and productive effects on livestock. Jabeen, Shah, Khan and Hayat (2010) also reported that Cadmium causes both acute and chronic poisoning, adverse effect on kidney, liver, vascular and the immune system.

The levels of Cadmium observed in sites 1,4 and 5 were similar to values reported for soils of municipal waste dump in South Western Nigeria (Bamgbose et al, 2000).

The concentration of Lead range from $16.555 \mathrm{mg} / \mathrm{kg}$ to $401.918 \mathrm{mg} / \mathrm{kg}$ with a mean value of $138.456 \mathrm{mg} / \mathrm{kg}$ which has exceeded the threshold limit of $100 \mathrm{mg} / \mathrm{kg}$ (Klobe, 1979). Lead was recorded in all the sites except S2 and S10. The high concentration could be attributed to burning of electronic waste materials such a refrigerators, used computers, cables, printers, photocopy machines, automobile tyres, batteries, air condition among others (Benedicta, 2017).

The high concentration of $\mathrm{Pb}$ could be attributed to burning of lead-containing products like scrap metals and batteries. Livestock that graze in these sites are likely to be exposed to health risks with regards to lead toxicity through the consumption of forage grasses growing in this area-Lead is reported to cause liver disorders in livestock especially in cattle. It is also reported that lead causes both acute and chronic poisoning and thus, posses adverse effects on kidney, liver, vascular and immune system.

Lead is a toxic heavy metal, which can be taken up by plant from the soil thereby interfering with the food chain. Lead is reported to exert its most significant effect on the nervous system (Zauro et al, 2013).

Lead ingestion has been associated with deleterious effects including disorder of central nervous system and lead is widely known to be toxic even at low concentration especially in young children.

The higher levels of $\mathrm{Pb}$ in $\mathrm{S} 1, \mathrm{~S} 4$ and $\mathrm{S} 5$ might be due to high traffic volume, automobile mechanical workshop area. It could also be due to the use of lead compound (Tetraethyl Lead), an additive in premium motor spirit (petrol) in automobiles and also because of its use in soldering metals and paints. The higher $\mathrm{Pb}$ concentrations in the study area maybe as a result of atmospheric deposition from anthropogenic sources including motor vehicle emissions, sewage sludge additions or through other industrial emissions.

The concentrations of Arsenic range from $0.338 \mathrm{mg} / \mathrm{kg}$ to $6.352 \mathrm{mg} / \mathrm{kg}$ with exception of S6, S7. The mean concentration is $2.520 \mathrm{mg} / \mathrm{kg}$ which is far below the permissible limit of $20 \mathrm{mg} / \mathrm{kg}$ (Kloke, 1979). Arsenic has been implicated in lung cancer, especially when arsenic compound inhaled is of low solubility. It has also been reported to have an effect on the liver by causing a disease termed cirrhosis (Aremu et al, 2010).

Chromium concentration range from $8.823 \mathrm{mg} / \mathrm{kg}$ at $\mathrm{S} 7$ to $26.228 \mathrm{mg} / \mathrm{kg}$ at $\mathrm{S} 4$. The mean concentration of $\mathrm{Cr}$ is $16.381 \mathrm{mg} / \mathrm{kg}$ far below the tolerable levels of $59.9 \mathrm{mg} / \mathrm{kg}$ (Kabata, 2011), 92mg/kg (Rudnik \& Gao, 2003). The high concentration of $\mathrm{Cr}$ at $\mathrm{S} 4$ could be as a result of the recycling of electronic wastes such as refrigerator, used computers, cables, printers, photocopy machines, automobiles tyres and batteries at the site (Benedicta,2017). The main sources of chromium in these dumpsites include textile materials, photographic materials, chromium steels, ceramics and paper (Iwegbue, 2010). Even in small amount, Cr. Stimulates the growth of agricultural crops, an excess of it however promotes various diseases (Vodyanitskii,2016)

The concentrations of Iron in the waste dumpsites studies ranged between $2027.155 \mathrm{mg} / \mathrm{kg}$ and $2966.230 \mathrm{mg} / \mathrm{kg}$, with a mean value of $2550.118 \mathrm{mg} / \mathrm{kg}$, which is below a normal range in soil while S9 having the highest concentrations. Iron is essential to all organisms, cofactor in many enzymes and hence proteins, essential trace metals in human metabolism necessary for oxygen-carrying ability of blood (McBride ,1994).

The major sources of iron in these sites include metallic scraps being co-deposited with domestic wastes. The high concentration of $\mathrm{Fe}$ could be partly due to $\mathrm{Fe}$ content of Lafia soil and partly due to high content of Fe-based waste materials generated through domestic and industrial wastes. Most of the $\mathrm{Fe}$ is bound to organic matter and residuals (Abdus-Salam, 2009).

The concentration of Zinc found in the study area ranged between $23.859 \mathrm{mg} / \mathrm{kg}$ to $1149.78 \mathrm{mg} / \mathrm{kg}$ with a mean concentration of $432.296 \mathrm{mg} / \mathrm{kg}$ far above tolerable level of 
300mg/kg(Kabata-Pendias, 2011; WHO/FAO, 2001) for soils. The presence of Zinc in the soil at various sites could be attributed to the occurrence of dry cells in the municipal waste and burning of electronic gadgets (Benedicta, 2017). Zinc is essential to all organisms; cofactor in numerous enzymes; necessary for growth healing and overall health (McBride, 1994).

The concentration of Selenium $(0.214-0.887 \mathrm{mg} / \mathrm{kg})$ with a mean concentration of $0.515 \mathrm{mg} / \mathrm{kg}$ was not detected in six out of ten waste dumpsites, however the mean concentration fall above the WHO/USEPA guidelines of $0.01 \mathrm{mg} / \mathrm{kg}$ with attendant high toxicity at high concentration. Selenium is essential to mammals and plants and aids vitamin E action and fat metabolisms (Mcmurry et al, 2010).

The concentrations of Copper ranged between $4.390 \mathrm{mg} / \mathrm{kg}$ and $93.153 \mathrm{mg} / \mathrm{kg}$ with a mean value of $25.32 \mathrm{mg} / \mathrm{kg}$. However the concentrations of copper fall within the tolerable level of $100 \mathrm{mg} / \mathrm{kg}$ (Kloke, 1979), with site 6 having the highest concentration. The mean concentration recorded could be attributed to burning of electronics gadgets and other copper-based wastes such as automobile spare parts. Copper is essential to organism, cofactor in redox enzymes and necessary to maintain blood chemistry. However, copper can be toxic at high concentration (McBride, 1994).

The concentrations of Manganese range from $69.890 \mathrm{mg} / \mathrm{kg}$ to $309.563 \mathrm{mg} / \mathrm{kg}$ with an average value of $175.161 \mathrm{mg} / \mathrm{kg}$ below threshold limits of $488 \mathrm{mg} / \mathrm{kg}$ (Kabata-Pendias, 2011). These concentrations of Mn observed in all the sites are similar to studies reported by Iwegbue et al, (2010) on some municipal waste dumps in Nigeria. However Mn is essential to all organisms, cofactor in numerous enzymes and necessary for carbohydrate metabolism and bone formation (McMurry,2010).

The concentrations of $\mathrm{Ni}$ were recorded in all the waste dumpsites except S7, S10. The concentrations of Ni ranged from $0.173 \mathrm{mg} / \mathrm{kg}$ to $5.474 \mathrm{mg} / \mathrm{kg}$ with a mean value of $1.973 \mathrm{mg} / \mathrm{kg}$ below the permissible limit of $100 \mathrm{mg} / \mathrm{kg}$ (Klobe, 1979; WHO/FAO, 1984). Nickel aids in the use of $\mathrm{Fe}$ and $\mathrm{Cu}$.

Barium concentration range from $0.365 \mathrm{mg} / \mathrm{kg}$ to $15.612 \mathrm{mg} / \mathrm{kg}$ with a mean value of $6.325 \mathrm{mg} / \mathrm{kg}$ below the tolerable level of $100 \mathrm{mg} / \mathrm{kg}$ reported (Vodyanitskii, 2016). Barium is highly toxic and no biological function.

Cobalt concentration range from $0.393 \mathrm{mg} / \mathrm{kg}$ to $4.123 \mathrm{mg} / \mathrm{kg}$ and a mean concentration of $1.635 \mathrm{mg} / \mathrm{kg}$ below permissible level of $20 \mathrm{mg} / \mathrm{kg}$ reported (Iwegbue, et al 2010). Cobalt is a cofactor in numerous enzymes and an essential trace element in human metabolism; and a component of vitamin B12.

\subsection{CONCLUSION AND RECOMMENDATION}

The concentrations of heavy metals in waste dumpsites within the study area were determined using Atomic Absorption Spectrophotometer (AAS). The study revealed that the concentrations of metals in these sites investigated; $\mathrm{Pb}, \mathrm{Cd}, \mathrm{Zn}, \mathrm{Se}$ were above the established threshold limits set by WHO/FAO and geochemical backgrounds reported in the literature. Their high concentrations could be attributed to increasing anthropogenic activities arising from waste disposal, burning of electronics wastes and high volume of traffic.

Their concentration posse serious risk to the environment. However, the concentrations of other heavy metals, As, Cr, $\mathrm{Fe}, \mathrm{Cu}, \mathrm{Mn}, \mathrm{Ni}, \mathrm{Ba} \mathrm{Co}$ fall below tolerable limits and of no serious harm to the environment. The study has shown that constant monitoring of heavy metals has become imperative in order to prevent excessive build -up of these metals in humans through the food chain. The study, a baseline information for future work has further shown how by our uncontrolled disposal of wastes, we are in danger of ruining our environment, jeopardizing our health; upsetting the balance of nature and poisoning the air, water, soil on which life so critically depend.

\subsection{ACKNOWLEDGMENTS}

I wish to express my heartfelt gratitude to TETFund through the Institutional Research Committee (IRC) of the Nasarawa State Polytechnic, Lafia for approval of funds for the research. I am also indebted to the following individuals for the roles they played in ensuring the success of the research. They are: Mr. P.P.Ikokoh of Sheda Science and Technology Complex (SHESTCO), Abuja for technical assistance, Mrs. Charity Nwobodo for typing the manuscript, colleagues of the Department of Science Laboratory Technology and other TETfund Research beneficiaries of Nasarawa State Polytechnic, Lafia for the shared knowledge.

\section{REFERENCES}

[1] Abdus-Salam, N; (2009) Assessment of Heavy metals pollution in dumpsites in Ilorin metropolis. Ethopian journal of Environment studies and management vol. 2(2)

[2] Adekunle, I.M; and Owolabi, D.A (2003): International journal of environmental issues.

[3] Akaeze, C.S (2001), Solid waste analysis, a research project of Chemistry/Biochemistry University of Uyo, Nigeria.

[4] Akwa, V.L; Binbol, N.C.,Samaila, K.I; and Markus, N.D. (2007), Geographical perspective on Nasarawa State. A publication of Geography Department, Nasarawa State University, Keffi, Nigeria.

[5] Ali, N; Oniye, S.J; Balarabe, M.L and Auta, J; (2005) Concentration of $\mathrm{Fe}, \mathrm{Cu}, \mathrm{Cr}, \mathrm{Zn}$, and $\mathrm{Pb}$ in Makera - Drain, Kaduna, Nigeria. ChemClass Journal Vol. 2,69-73

[6] Anake, W.U; Adie, G.U; and Osibanjo, O (2009) Heavy metals pollution at municipal solid waste dumpsites in Kano and Kaduna States in Nigeria. Bull. Chem. Soc. Ethiop. Vol 23(1).

[7] Anzene, J.S and Malu, P.S (2014) Determination of levels of eight trace metals in ground water sources within and around Lafia metropolis. International Journal of Innovative science, Engineering and Technology vol. 1;5

[8] Analytical Assessment of some trace metals in soils around the major industrial areas of North West Nigeria. Vol.2(6) Trends in Applied Sciences Research

[9] Aremu, M.O; Atolaiye, B.O; and Labaran, L (2010) Environmental implication of metal 
[10] concentrations in soil, plant foods and pond in area around the derelict Udege Mines of Nasarawa State, Nigeria. Bull.chem.soc.Ethiop 24(3)

[11] Benedicta, Y. F. M; Emmanuel A; Dzidzo, Y.T; and Frank, N. (2017) Heavy metals concentration and distribution in soils and vegetation at Korle Lagoon area in Accra,

[12] Ghana ._Environmental chemistry, pollution and waste management research Article, cogent environmental science. Environmental GeoChemistry and Health (2018). Pollution indices as useful tools for the comprehensive evaluation of the degree of soil contamination. A review Vol. 40 (6).

[13] Edovi, O.S; and Kpee, F (2010); Index modes assessments of heavy metal pollution in soils within selected abattoirs in Port Harcourt, Rivers State, Nigeria; Singapore Journal of Scientific Research ISSN 2010-006X.

[14] Getachew,D; and Hebtamu, D. (2015) Heavy metal pollution of soil around solid waste dumping sites and its impact of Shashemane open landfill, Ethiopia. Journal of Environment and earth science vol 5 (15).

[15] Ikpesu, J.E. and Dickson, Y. (2016); Determination of Heavy metals in soils in Nigerian Agip oil company Obiafor/Obrikom Environs. Journal of Multidisciplinary Engineering Science and Technology (JMEST Vol.3 (2).

[16] Iwegbue C;M.A; Nwajei; G.E; Overah, C.L; and Ogala, J.E (2010);1) Determination of trace metal concentrations in soil properties of municipal waste dumpsites in Nigeria

[17] Iwegbue, C.M.A, Enuh, F.N, Isirimah, O.N., and Egun, A.C (2007) Fractionation, characterization and speciation of heavy metals in composts and compost amended soils, Afr. J. Biotechnol 6(2) 067-078

[18] Kabata-Pendias , A. (2011). Trace elements of soils and plants ( $4^{\text {th }}$ Ed.)...ppp 28-534CRC Press, Taylor and Francis groupKloke, A, (1979). Content of arsenic, cadmium, chromium, fluorine, lead, mercury and nickel in plants grown on contaminated soils, United Nations -ECE symposium, Geneva. Pp51-53.

[19] McBride, M.B (1994); Environmental Chemistry of soils; Oxford University Press.

[20] McMurry, J; Castellion, N; Ballantime, D.S; Hoeger, C.A; and Peterson, V.E (2010).

[21] Fundamental of General, organic and biological chemistry, $6^{\text {th }}$ Ed. Practice Hall.

[22] McLennan, S.M (2001). Relationships between the trace element composition of sedimentary rocks and upper continental crust. Geochemistry, Geophysics, Geosystems Article No. 2000GC000109.

[23] Mirelys, R.A; Alfredo, N; Olegario, N.U, Christenes, W.A; Adriana, M.A; Caroline, N.B, Ygor,

[24] J.A.B (2015); Background concentrations and reference values for heavy metals in soils of Cuba. Environment Monit Access $187 ; 4198$

[25] Mustapha, B.J Khalid D.K Zakari, A; (2015) comparative assessment of heavy metals concentration in the vicinity of tannary industries, Kumbotso old dumpsite and river challawa confluence, at Challawa industrial estate, Kano State, Nigeria. Int. Journal of Innovative research and development; www.ijird.com vol 4(6)

[26] Obaliagbon, O.K and Olowoyoba, G.B (2006): "Distribution of some heavy metals in Leachates forms a municipal waste dumpsite". Paper presented at the international conference on engineering Research and Development, University of Benin, Benin city.

[27] Okegye, J.I. (2000). Heavy metals pollution from mining practices; a case study of UDEGE MBEKI, A paper presentation at Nasarawa State Polytechnic $3^{\text {rd }}$ ASUP Conference (Unpublished).

[28] Pueyo, M., Mateu, J., Rigol, A vidal, M., Lopez Sanchez, J Rauret, G. (2008) Use of the modified BCR three-step sequential extraction procedure for the study of trace element dynamics in contaminated soils. Environmental pollution 152330.341

[29] Rudnick, R.L \& Gao, S. (2003). Composition of the continential crust, treatise on geochemistry. Treatise on Geochemistry, 3 1-64.

[30] Sanayei, Y., Ismail N and Talebi, S.M (2009): Determination of heavy metals in Zayandeh Road River, World Applied Sciences Journal 6(9) 1209-1214;
[31] Song, Q.J and Greenway, G.M (2006): Kinetic speciation of BCR reference materials. Intern J. Environ. Anal. Chem 8615). 359366

[32] Sylvester, C. I; Sunday, E.B. and Elijah , I. O (2017); Assessment of pollution load indices of Heavy Metals in cassava mill Effluents of contaminated Soil: A case study of small-scale processors in a rural community in the Niger Delta; Nigeria. Bioscience Methods Vol.8 (1), 1-17.

[33] Uba, S., Uzairu, A., Harrison, G.F.S, Balarbe, M.L., and Okunola, O.J (2003) Assessment of heavy metals bioavailability in dumpsites of Zaria metropolis, Nigeria African Journal of Biotechnology 7(2): 122-130

[34] USEPA (1986): Test Methods of Evaluation for solid waste (USEPA S/W 846 UEPA Washington DC)

[35] Vodyanitskii, Y.N; (2016). Standard for the contents of heavy metals in soils of some states. Annals of Agrarian Science (14).

[36] Wang, J., Chen, S, Tion, M., Zheng, X., Gonzales., L., Ohura, T., Massey Simonich, S.L (2012). Inhalation cancer risk associated with exposure to complex polycyclic aromatic hydrocarbon mixtures in an electronic waste and urban area in south china Environmental Science and Technology 46 (17),9745-9752.

[37] Wang., X., Y., Li, Q, B., Luo, Y.M., Ding. Q., Xi, L.M., Ma, J.,M., Cheng, C. L. (2010).

[38] Characteristics of sources of atmospheric polycyclic aromatic hydrocarbons (PAHs) in Shangai, China. Environmental Monitoring and Assessment.165(1-4); 295-305.

[39] WHO/FAO. (2007). Joint FAO/WHO Food Standard Programme Codex Alimentarius Commission $13^{\text {th }}$ session , report of the thirty eight session of the codex committee on food hygiene, Houston

[40] Zauro, S.A; Dabai, M.U; Tsafe A.I; Umar, K.J and Lawal, A.M (2013); Extent of some heavy metals contaminator in soil of farmlands around Sokoto Metropolis. European Scientific journal vol $9(3)$ 